 \\ IJ@TA Indonesian Journal of Tropical Aquatic
}

\section{Simple storage of sperm cells using a combination of coconut water and glycerol against the motility and viability of Koi Fish sperm (Cyprinus carpio)}

Agista Tsani Untsa, ${ }^{1, a}$, Ganjar Adhywirawan Sutarjo ${ }^{1, b, *}$, Riza Rahman Hakim¹,c

${ }^{1}$ Fisheries Department, Faculty of Agriculture and Animal Science, University of Muhammadiyah Malang, Indonesia.

aagista_426021@webmail.umm.ac.id bganjar@umm.ac.id crizarahman@umm.ac.id *Corresponding author

\section{ARTICLE INFO ABSTRACT}

Keywords:

Motility

Viability

Sperm

Cyprinus carpio

Reproduction
Fish sperm is a crucial part of fish reproduction, especially for Cyprinus carpio. This study aimed to determine the effect of coconut water and glycerol on the motility and viability of sperm koi fish (C. carpio) and the best treatment on sperm storage of Showa koi fish. This research was conducted for 45 days at Installation of Punten Freshwater Cultivation - Malang. The completely randomized design (CRD) used with five treatments and three replications. The treatment comes in $750 \mu$ l coconut water, $500 \mu \mathrm{l}$ coconut water, and $250 \mu \mathrm{l}$ glycerol, $375 \mu \mathrm{l}$ coconut water and $375 \mu \mathrm{l}$ glycerol, $250 \mu \mathrm{l}$ coconut water and 500 $\mu$ l glycerol, and $750 \mu$ glycerol (P1, P2, P3, P4, and P5, respectively). Briefly, the sperm is stored at a low temperature $\left(4^{\circ} \mathrm{C}\right)$. Observation of sperm motility used sperm cell dilution contained physiological $\mathrm{NaCl}$, while the viability calculation used eosin $2 \%$ by the smear method. Motility and viability investigation were employed were carried out under a microscope with $400 \mathrm{x}$ magnification. The results revealed that the addition of coconut water and glycerol had a significant difference on the motility and viability of sperm koi fish. It could survive 96 hours of storage, but the longer motility and viability would decrease. The P3 showed the best result compared to others. The P3 had an average motility scale of $96-5.00$ and the average viability is $87.38 \%$. Based on it, the treatment could increase the motility and viability of koi fish sperm.
How to cite:

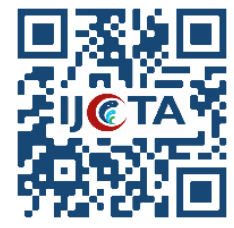

Untsa AT, Sutarjo GA, Hakim RR. 2019. Simple storage of sperm cells using a combination of coconut water and glycerol against the motility and viability of koi fish sperm (Cyprinus carpio). IJOTA. 2(1): 25-32.

DOI: https://dx.doi.org/10.22219/ijota.v2i1.7327

Copyright (c) 2019, Untsa et al. This is an open access article under the CC-BY-SA license

\section{Introduction}

Koi Showa strains including fish that have economically important, Koi fish with superior criteria can be used as koi fish contest so many farmers try to increase their production. To increase production, the many methods that many farmers do, namely natural and artificial spawning. The 
main factor in increasing production activities requires a superior parent that has matured the gonads so that the seeds are produced which have good quality and quantity of sperm cells. In order to produce superior sires, it takes a long time and costs are not cheap, therefore the superior parent needs to be as optimal as possible. At the time of the reproductive season, superior parent sperm cell storage needs to be done so that when the sperm is needed it can be directly used without having to wait and bring the gonad mature male parent back. At sperm storage, a dissolvent is needed that can protect sperm from low temperatures and provide an energy source during the storage process, because if there is no addition of diluents, the stored sperm will be damaged and cause (Zairin et al., 2005).

Simple sperm storage has the advantage that it can be stored for a long period of time so that it can be used when needed. The life span of sperm carp (C. carpio L.) in fresh water lasts only 72 seconds. While the life span of sperm that has not been contaminated with any liquid or solution lasts 3 minutes 47 seconds. Sperm storage requires diluents that can protect sperm from low temperatures and provide a source of energy during the storage process, because without sperm dilution the material will be damaged and die during storage. The required diluent can supply isotonic and nutritional properties that can maintain the appropriate osmotic pressure and electrolyte balance, so that sperm can survive. Dissolvent that can be used as a dissolvent is coconut water, because coconut water can be used as an energy source for spermatozoa (Leboeuf et al., 2000).

Coconut water contains glucose and fructose which is also contained in sperm, so that spermatozoa can be used as an energy source, and it is hoped that sperm will survive during storage. In addition to coconut water as a diluent, the addition of glycerol is also needed as a protective agent for spermatozoa during the storage process. Addition of glycerol in the dissolvent is thought to protect sperm from low temperature cold shock which can kill sperm cells (Novianto et al., 2014).

This study aims to determine the effect of sperm cell storage using a combination of coconut water with glycerol on the motility and viability of spermatozoa of koi fish ( $C$. carpio). This study refers to a previous study conducted by Isnan et al. (2013) on the addition of coconut water and glycerol in sperm storage to motility and fertility of spermatozoa of $C$. carpio with a length of 4 days.

\section{Material and methods}

\subsection{Research material.}

The material used in this study is the male koi fish from the Unit Pengelola Budidaya Air Tawar (UPBAT), Punten, Batu City, East Java. The materials used in this study include sperm cells, glycerol, coconut water, eosin, and physiological $\mathrm{NaCl}$. The tools used include microscopes, Micropipette, Refrigerator, Hemocytometer, Glass objects, Glass cover, Analytical scales, Thermometers, Mikrotube racks, Beaker glass, Spatula, and Optilab. The primary test method is the motility of the assessment qualitatively and adjusted to the predetermined scale, and the second test variable is viability calculated.

\subsection{Research methods.}

The method used in this study is an experimental method. The design of the study used in this study was a Completely Randomized Design (CRD). RAL is a design where treatment is fully involved randomly in experimental units. Sperm cells were stored using different combinations of 
coconut water and glycero/ with 5 treatments and 3 replications. Treatment $1: 0.25 \mathrm{ml}$ sperm +0.75 $\mathrm{ml}$ coconut water. Treatment 2: $0.25 \mathrm{ml}$ sperm $+0.50 \mathrm{ml}$ coconut water $+0.25 \mathrm{ml}$ glycerol. Treatment 3: $0.25 \mathrm{ml}$ sperm $+0.375 \mathrm{ml}$ coconut water $+0.375 \mathrm{ml}$ glycerol. Treatment $4: 0.25 \mathrm{ml}$ sperm $+0.25 \mathrm{ml}$ coconut water $+0.50 \mathrm{ml}$ glycerol. Treatment 5: $0.25 \mathrm{ml}$ sperm $+0.75 \mathrm{ml}$ glycerol. The primary test method is the motility of the assessment qualitatively and adjusted to the predetermined scale, and the second test variable is viability calculated using the formula:

$$
\text { Sperm viability }=\frac{\text { total of live spermatozoa }}{\text { live }+ \text { dead spermatozoa }} \times 100 \%
$$

\subsection{Data Analysis.}

Data obtained then carried out variance or analysis of variance (ANOVA) to determine the effect or not treatment of the results of the study, if it is significant then carried out by BNT test to determine the optimal treatment at the $95 \%$ confidence level to compare the values between treatments descriptively.

\section{Results and Discussion}

\subsection{Observation of Fresh Sperm Quality.}

The observation of sperm of koi fish that have not been treated is based on macroscopic examination. Fresh sperm examination tables for koi before treatment can be seen in Table 1.

Table 1. Observation of fresh sperm Observation

\begin{tabular}{|c|c|c|}
\hline Criteria & Results & Reference (Novianto et al., 2014) \\
\hline Sperm volume sperm & $4.03 \mathrm{ml}$ & $2-3 \mathrm{ml}$ \\
\hline Colour sperm & Milk white & White milk \\
\hline Odor & Fishy / typical sperm smell & Odor sperm / fishy \\
\hline pH sperm & 7 & $7-6$ \\
\hline Consistency & Thick & Thick / thick \\
\hline Concentration of sperm & $26.1 \times 10^{9}$ cells $/ \mathrm{ml}$ & $7.6-28 \times 10^{9}$ cells $/ \mathrm{ml}$ \\
\hline Weight & 1800 gram & Min 500 gram \\
\hline Age & 12 months & 8 months \\
\hline
\end{tabular}

Based on the results of the macroscopic and microscopic examination of fresh sperm, the koi fish is worthy to be sampled or stockpile of sperm storage. This is because the fresh sperm produced is $4.03 \mathrm{ml}$ from one male parent weighing $1.8 \mathrm{~kg} \mathrm{ind}^{-1}$, and 10 months old. The $\mathrm{pH}$ of the sperm of koi during the study was 7 which were neutral and the consistency of sperm was thick or thick. The fresh sperm concentration that the researchers observed during the study was $26.1 \times 10^{9} \mathrm{cells} \mathrm{ml}^{-1}$.

\subsection{Motility of Koi Fish Sperm.}

Sperm motility is the ability of sperm to move using the energy he has in his body. Assessment of sperm movement seen from the way the sperm moves, sperm is moving progressively active, slowly progressive, and not progressive. Active progressively, the sperm can move forward rapidly, progressively slowly, where the sperm moves slowly. Not progressive, the sperm moves in a place or moves around in circles. The motility of sperm is determined by the number of sperm that can 
move from a field of view. The calculation of sperm motility was carried out using an objective assessment which was translated by descriptive which was then adjusted to the scale in the motility table by Guest et al., (1976) in Hasan (2013). The following are observations of the sperm motility values of koi fish from each different treatment and the length of storage time.

Based on observations of the mobility carried out for 96 hours, there was a difference in the treatment of coconut water and glycerol to the sperm motility of koi fish. The average sperm motility ratio of P1 was 4.87, P2 treatment was 4.27, P3 treatment was 4.13, treatment P4 was 3.87, and treatment P5 was 3.80. Based on the results of the sperm motile ratio in Figure 7, it is known that the highest motility ratio is P3 (4.87), P5 (4.27), P4 (4.13) and the lowest results are P2 (3.87) and P1 (3.53).

Results of analysis of variance (ANOVA) Motility of Koi Fish Sperm shows that there are very significant differences, this can be shown from the greater $\mathrm{F}$ count (coconut water and glycerol) from $\mathrm{F}$ table 0.01 which shows that the treatment has a very significant effect on the motility of sperm koi. $\mathrm{F}$ count (length of time) is greater than $\mathrm{F}$ table 0.01 which indicates that the length of time has a very significant effect on sperm motility of koi fish and, $F$ count (interaction of coconut water and glycerol with length of time) is greater than $\mathrm{F}$ table which indicates that treatment very significant effect on the motility of sperm koi.

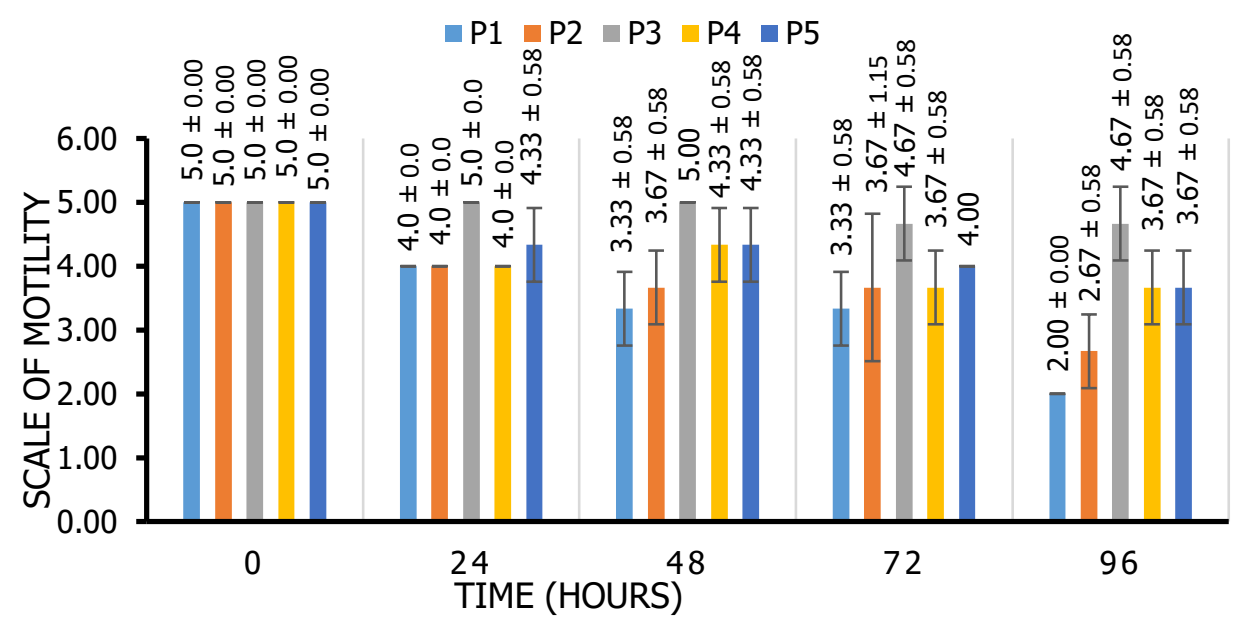

Figure 1. Sperm motility of Koi Fish

The smallest real difference test results show that there are significant differences from each pair of treatments and there are treatments that are not significantly different from each pair of treatments. The best results were obtained by P3 treatment with diluent concentrations (375 $\mu$ l of coconut water and glycerol) which at each dilution concentration did not show a significant difference. While the lowest results were obtained on P1 with diluent concentration ( $750 \mu$ l coconut water did not use glycerol) which at each dilution concentration showed a significant difference. According to research conducted by Sartoyo (2005) stored sperm using physiological $\mathrm{NaCl}$ with sperm concentration of $40 \times 10^{6}$ cells and storage at a temperature of $-10{ }^{\circ} \mathrm{C}$, the average motility value only reached $20.48 \pm 4.38$ with a storage time of 6 hours.

Based on the treatment and observations that have been made the treatment of P3 is the best, it is assumed that the high average motility scale is influenced by an isotonic environment with cell fluids, where the isotonic solution contains sodium, potassium, magnesium which can replace cell fluids when the cells carry out metabolic processes. The availability of sufficient energy sources for sperm, where coconut water contains glucose which can be directly used by sperm for energy 
reserves. Sperm cells are also able to absorb fructose in coconut water, fructose will be simplified again with the help of the fructokinase enzyme, this enzyme will bind phosphate to the molecule then fructose is converted to glucose. Storage at low temperatures can also reduce sperm to move, so the energy released by sperm is only used to survive during storage so that the decrease in $\mathrm{pH}$ becomes inhibited.

This is confirmed by the statement of Udhardt et al., (2005) which states that coconut water also contains minerals such as potassium and sodium. Minerals are needed in metabolic processes, also needed in the formation of cofactors of extracellular enzymes by cellulose-forming bacteria. Besides containing minerals, coconut water also contains vitamins such as riboflavin, thiamine, biotin. Coconut water also contains carbon in the form of simple carbohydrates, such as: glucose and fructose. So that coconut water is able to replace the energy needed by spermatozoa. The explanation above is supported by Isnan et al. (2013) statement that several things need to be considered when sperm observation, starting from superior sperm quality and sperm need to mix with diluent materials with appropriate concentration and guarantee physical and chemical needs. The use of diluents is intended to reduce sperm activity, thus inhibiting energy use and can prolong the life of the sperm. Reduced sperm activity causes the production of lactic acid to decrease, so that a decrease in $\mathrm{pH}$ becomes inhibited, consequently reducing the negative influence on the life of sperm.

Based on the treatment and observations that have been made, the results show that treatment P1 has the lowest average motility value. The low average value of the motility scale is thought to be influenced by the concentration of diluents. In the absence of glycerol, sperm cannot survive at low temperatures, so the energy that must be used to survive is used by sperm cells to carry out cell metabolism. The metabolic process (glucose breakdown) that continues to occur will produce a by-product in the form of lactic acid if the lack of supply of oxygen diffuses into the cell. Then $\mathrm{CO}_{2}$ will increase and $\mathrm{pH}$ will decrease. If the sperm storage environment does not support the sperm will decrease in quality (Suswahyuningtyas, 2007).

This is reinforced by the opinion of Hasan (2013) which states that storage for a long time at temperatures $<5{ }^{\circ} \mathrm{C}$ sperm cells will be exposed to cold shock and sperm will experience a decrease in quality or even the worst possibility that sperm will die faster. This is due to the increase in the number of spermatozoa that die and are damaged by cold temperatures, the availability of energy in the diluent will decrease, and increase the acidity of the cement. The energy needed by sperm is provided by simple sugars or monosaccharides such as fructose and glucose. Addition of fructose or glucose in diluents is useful to support sperm motility. Because the process of forming Adenosine Triphosphate (ATP) and Adenosine Diphosphate (ADP) must continue to be done so that motility can continue.

\subsection{Viability of Koi Fish Sperm.}

The viability is one indicator to determine the assessment of sperm quality and to determine the number of sperm that are living or not living or dead. A high percentage of life means more numbers of living spermatozoa. For the fertilization process, it is necessary to have sperm that are alive and have a regular shape, so that the higher the percentage of living power, the better the fertilization rate. The following are the results of calculating the average value of sperm viability of koi from each different treatment and different length of time. 


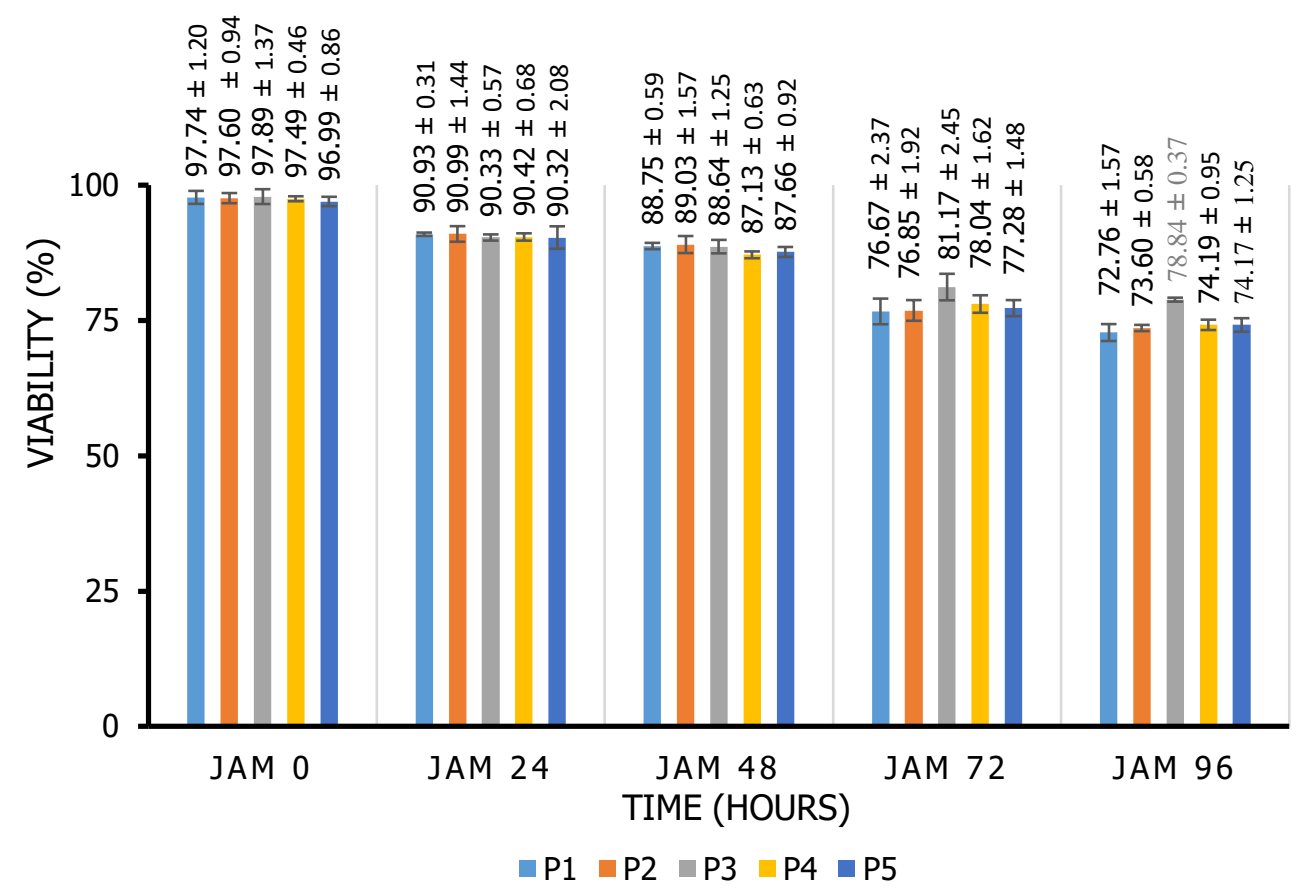

Figure 2. Histogram Percentage of Koi Sperm Viability

Based on observations of sperm viability carried out for 96 hours, there was a difference in the treatment of coconut water and glycerol in the sperm viability of koi fish. Average treatment sperm viability ratio $\mathrm{P} 1$ was 85.28 , P2 treatment was $85.61, \mathrm{P} 3$ treatment was 87.38 , treatment P4 was 84.45 , and treatment P5 was 85.28. Based on the results of the sperm motile ratio in figure 9, it is known that the highest motility ratio is P3 (4.87), P5 (4.27), P4 (4.13) and the lowest yield is $P 2$ (3.87) and P1 (3.53). After observing, then the data is processed and presented to produce data which is then analyzed by analysis of variance (ANOVA) to determine whether there is an effect of differences in the concentration of coconut water and glycerol on the sperm viability of koi fish.

Results of analysis of variance (ANOVA) Motility of Koi Fish Sperm shows that there are very real differences, this can be shown from $\mathrm{F}$ count (coconut water and glycerol) greater than $\mathrm{F}$ table 0.01 which indicates that the treatment has a very significant effect on the sperm viability of fish koi. $F$ count (length of time) is greater than $F$ table 0.01 which indicates that the length of time has a very significant effect on the sperm viability of koi fish and, $F$ count (interaction of coconut water and glycerol with length of time) is greater than $F$ table which indicates that treatment very significant effect on the viability of sperm koi $(P>0.05)$.

Results of the smallest real difference test indicate that there is a treatment that is not significantly different from each treatment pair and the real difference from each pair of treatments. The P5 treatment was not significantly different for all treatments. P1 treatment was not significantly different from P3 treatment. P4 treatment was not significantly different from treatment P3 and P1. P2 treatment was not significantly different from treatment P3, P1, and P5. P3 treatment significantly affected the treatment of P3 and P1, but not significantly different from the treatment P5 and P2.

The best results were obtained in treatment P3 with diluent concentrations ( $375 \mu$ l of coconut water and glycerol) which at each dilution concentration did not show a significant difference. While the lowest results were obtained at P5 with the concentration of diluent (not using coconut water and added $750 \mu \mathrm{l}$ of glycerol) which at each dilution concentration showed a significant difference. The lowest results from this study can be said that sperm is still feasible to do storage because the 
average value of viability is $85.28 \%$. This is supported by the opinion of Arianti (2013) which states that the minimum percentage of living sperm to be used for storage is $80 \%$.

The value of sperm viability at the storage of the combination of coconut water and glycerol shows that the longer the sperm storage time, the lower the viability value. It is known that sperm stored using physiological $\mathrm{NaCl}$ (sodium chloride) with a temperature of $-10{ }^{\circ} \mathrm{C}$ concentration of 60 million sperm can only survive at 6 hours of storage with an average viability value of $68.7 \pm 5.46$. So that it can be concluded based on the treatment and observation that the P3 treatment is the best, it is assumed that the high average viability value is influenced by the concentration of the dilute solution which is balanced, the difference in osmotic pressure inside and outside the cell will be more stable so the sperm can survive in the storage process. If the concentration of the dilute solution is balanced it will prevent death in the cell due to the occurrence of hypotonic and hypertonic sperm cells. Storage at low temperatures $\left(4^{\circ} \mathrm{C}\right)$ also affects the high value of viability because low temperatures can inhibit sperm cells from carrying out mechanical or chemical activities. Storage at low temperatures is done in stages to reduce cold shock drastic. Cold shock will cause death in sperm cells, where the ice flower will grow and can penetrate the sperm cell wall. The use of glycerol in storage functions as a cell protector from cold shock because there is lecithin in glycerol which will work as a spreading layer of sperm cells (Hidayaturrahmah, 2007).

The discussion above is reinforced by the statement Medeiros et al. (2002) which states that electrolyte fluid imbalance due to the process of spermatozoa metabolism can cause damage to the spermatozoa cell membrane. This damage is due to an unbalanced exchange of intracellular and extracellular solutions. Opinion from Sartoyo (2005) who argues that sperm diluents must contain lipoprotein or lecithin which will be tasked to coat spermatozoa from cold millions (cold shock) and is a reducing source to protect cellular enzymes containing sulfhydryl.

Based on the treatment and observations that have been made the results show that treatment P5 has the lowest average viability value. The low average value of the scale of viability is thought to be influenced by the concentration of dissolvent that are less balanced. The imbalance of the solution will affect the process of metabolism in cells and can cause damage to the sperm cell membrane. This damage results from the exchange of solutions inside and outside the cell between diluents and sperm. The process of diluting the cement with less appropriate concentration can cause damage to the plasma membrane. damage to membrane cells will affect the semipermeable nature of sperm cells, so that sperm cells cannot select substances that enter and exit. This causes sperm to absorb the eosin color that is around it. Therefore the dead sperm will be red when staining.

Lack of energy reserves during storage, the absence of giving coconut water as food reserves so that some sperm are unable to maintain their lives. Living sperm can survive due to the influence of low temperatures that can prevent sperm from carrying out its activities. This is reinforced by the opinion of Medeiros et al. (2002) which states that the reduction in food reserves at the time of storage, and the presence of electrolyte fluid imbalances due to the process of spermatozoa cell metabolism can cause damage to spermatozoa cell membranes. This damage is caused by the exchange of intracellular and extracellular solutions from diluents with spermatozoa cells due to differences in concentration. The process of diluting cement can cause damage to the plasma membrane and reduce motility. Damage to spermatozoa cell membranes will have an impact on membranes whose semipermeable properties are no longer able to select the exchange of substances from inside and outside, so that when the eosin color test is carried out the substance enters the plasma. So that the dead sperm will absorb the red color from eosin. 


\section{Conclusion.}

Based on the description of the discussion and the statistical test of the research results, it can be concluded that: Storage of sperm cells using a combination of coconut water and glycerol has a very significant effect on the condition of the motility and viability of koi sperm (Cyprinus carpio) in a 96 hour storage period. Better treatment in addition of coconut water and glycerol to the motility and viability of sperm koi is in treatment P3 with a combination of $375 \mu$ of coconut water and 375 $\mu$ l of glycerol.

\section{References}

Arianti. 2013. Determination of time equilibration on freezing horse cement using skim milk diluent materials. Animal Reproduction. 9(3): 145-152.

Hidayaturrahmah. 2007. Waktu motilitas dan viabilitas spermatozoa Ikan Mas (Cyprinus carpio L.) pada beberapa konsentrasi larutan fruktosa. Bioscientiae. 4(1): 9-18.

Hasan F. 2013. Pemberian Berbagai Jenis Madu Dengan Rasio Pengenceran Berbeda Setelah Masa Penyimpanan Terhadap Kualitas Sperma Ikan Patin Siam (Pangasius hypopthalamus). Repository IPB : Bogor.

Isnan F, Basuki, Susilowati. 2013. Penambahan air kelapa dan gliserol pada penyimpanan sperma terhadap motilitas dan fertilitas spermatozoa Ikan Mas (Cyprinus carpio L.). Journal of Aquaculture Management and Technology. 2(1): 51-65.

Leboeuf B, Restall B, Salamon, S. 2000. Production and storage of goat semen for artificial insemination. Animal Reproduction Science. 62: 113-141.

Medeiros FC, Evans G, Maxwell WMC. 2002. Cryopreservation of stallion sperm using different amides. Theriogenology. 58: 273-276.

Novianto, Sudarno, Endang DM. 2014. Pengaruh perbedaan konsentrasi gliserol dalam susu skim kuning telur untuk proses penyimpanan sperma beku terhadap motilitas dan viabilitas spermatozoa ikan patin (Pangasius pangasius). Jurnal IImiah Perikanan dan Kelautan. 6(1): 35-43.

Sartoyo. 2005. Pengaruh Konsentrasi Dan Suhu Penyimpanan Terhadap Kualitas Sperma Ikan Mas Koki (Carassius auratus). Repository Unair : Surabaya.

Suswahyuningtyas. 2007. Pengaruh penambahan streptomycin dalam skim kuning telur sebagai pengencer terhadap kualitas semen ikan mas (Cyprinus carpio L.). Jurnal Protein. 15(2): 145152.

Udhardt U, Hesse S, Klemm D. 2005, Analytical investigation of baterial cellulose. Macromolecular Symposia. 223(1): 201-212.

Zairin M, Handayani S, Supriatna. 2005. Kualitas sperma Ikan Batak (Tor Soro) hasil kriopreservasi semen menggunakan dimetilsulfoksida (DMSO) dan gliserol. Jurnal Akuakultur Indonesia. 4(2): $145-151$. 